\title{
Psychological Capital and Burnout Relationship of Employees in Turkey: A Meta-Analysis within the Scope of Sub-Dimensions
}

DOI: $10.26466 /$ opus. 905267

*

\author{
Metin Ocak * Özgür Uğur Arıkan ** \\ * Doç. Dr., Toros Üniversitesi, İktisadi İdari ve Sosyal Bilimler Fakültesi, Mersin/Türkiye \\ E-Posta: metin.ocak@toros.edu.tr ORCID: 0000-0002-1142-3661 \\ ** Arş. Gör. Dr., Toros Üniversitesi, İktisadi İdari ve Sosyal Bilimler Fakültesi, Mersin/Türkiye \\ E-Posta: ozgurugurarikan@gmail.com ORCID: $\quad$ 0000-0003-1402-1761
}

\begin{abstract}
This study is based on a meta-analysis, conducted in Turkey between the years 2012-2020, that focuses on the psychological capital (PsyCap) and burnout sub-dimensions'relationship of employees working in both public and private sectors. The analysis was carried out based on the correlation coefficients and sample sizes of 9 studies with a total sample size of 2280 that complied with the previously established criteria. After the stages of literature review and coding, calculating the effect sizes of each studies that meet the criteria, performing basic meta-analysis and calculating the general effect size, estimation and correction stages of publication bias were carried out with Comprehensive Meta Analysis (CMA) V3 software. The general effect size was calculated through the random effect model as a result of the homogeneity test. Additionally, it was concluded that there was no publication bias by examining the funnel plot, fail-safe number and Tau coefficient. According to the results of analyzes, all hypotheses claiming that there is a negative relationship between employees' psychological capital and burnout sub-dimensions working in Turkey were proven. It was revealed that the general effect sizes under the random-effect model varied between weak and medium levels. These results have been discussed within the scope of the literature, and suggestions have been developed for practitioners and future studies.
\end{abstract}

Key Words: Psychological capital, burnout, sub-dimensions, employees, meta-analysis 


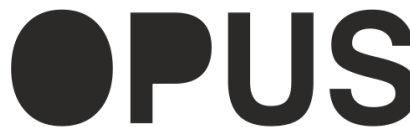

Uluslararası Toplum Araştırmaları Dergisi International Journal of Society Researches
E-ISSN: 2528-9535

Yıl Year. 11

Cilt Volume: 18

Sayı Issue: Yönetim ve Organizasyon Özel Sayısı

Temmuz July 2021

Makalenin Geliş Tarihi Received Date: 29/03/2021 Makalenin Kabul Tarihi Accepted Date: 21/05/2021

\title{
Türkiye'de Çalışanların Psikolojik Sermaye ve Tükenmişlik İlişkisi: Alt Boyutlar Kapsamında Bir Meta Analiz
}

\begin{abstract}
Bu çalışmada Türkiye'de 2012-2020 yılları arasında kamu ve özel sektörde çalışanların psikolojik sermayeleri (PsyCap) ile tükenmişlik düzeylerinin alt boyutları arasındaki ilişkiye yönelik yapılan çalışmaların bir meta analizi yapılmıştır. Analize dahil edilecek yayınları belirlemek amacıyla oluşturulan kriterlere uyan toplamda 2280 örneklem büyüklü̈̆̈̈ne sahip 9 çalışmanın korelasyon değerleri ve örneklem büyüklükleri kullanılarak meta analizi gerçekleştirilmiştir. Alanyazın taraması ve kriterlerin belirlenerek araştırmaların kodlanması, kriterleri karşılayan araştırmalardan analize dahil edilenlerin etki büyüklüklerinin hesaplanması, temel meta analizinin yapılması ve genel etkinin hesaplanması, yayın yanlılığının tahmin edilmesi ve düzeltilmesi aşamaları Comprehensive Meta Analysis (CMA) V3 yazılımı ile gerçekleştirilmiştir. Genel etki büyüklüğ̈̈nün hesaplanmasında yapılan homojenlik testi sonucunda rassal etki modeli kullanılmıştır. Yayın yanlılı̆̆ının hesaplanmasında huni grafiği, hata koruma sayısı ve Tau katsayısı birlikte yorumlanarak yayın yanlılığının olmadı̆̆ı değerlendirilmiştir. Türkiye'de çalışanların psikolojik sermaye ve tükenmişlik düzeylerinin alt boyutları arasındaki ilişkiye yönelik yapılan meta analizi sonucunda çalışanların psikolojik sermayelerinin tükenmişlik düzeyleri ile alt boyutlar kapsamında negatif yönde ilişkili olduğuna dair tüm hipotezler doğrulanmıştır. Rastgele etki modeli altında genel etki büyüklüklerinin zayıf ve orta düzeyler arasında değiştiği ortaya çıkmıştır. Elde edilen bu sonuçlar alanyazın kapsamında tartışılmış ve bundan sonraki çalışmalar ile uygulayıcılara yönelik öneriler geliştirilmiştir.
\end{abstract}

Anahtar Kelimeler: Psikolojik sermaye, tükenmişlik, alt boyutlar, çalışanlar, meta-analiz 


\section{Introduction}

Nowadays the incremental pace of transition and tough competition conditions trigger individual success to come to the fore. Employees in different sectors are exposed to various difficulties in the shadow of increasing competitive pressure and high-performance expectations of managers. The incompatibility between individuals and the natural components of their work, increased workload, oppressive control mechanisms, reward-punishment systems, organizational culture, and intra-organizational hierarchical tightness can lead to burnout. Burnout can be expressed as an undesirable situation for organizations in the struggle to achieve sustainable competitive advantage. All critical resources needed by organizations are used to gain a competitive advantage (Prahalad and Hamel, 1990). Burnout can cause employees, who are one of the resources that are difficult to imitate for organizations, to lose motivation, act with the intention of leaving their job, take sanitary leave very often, or work inefficiently by extending short breaks during the day as much as possible (Maslach et al., 2001). Organizations in a competitive environment, with a resource-based perspective; focus on gaining impetus from their vital, inimitable, and unique resources (Hashim, 2000). Accordingly, it is considered as an undesirable situation for individuals who can create value for organizations to be prisoners of their own internal problems and feelings of burnout. However, just like organizations, people try to overcome their problems by getting strength from their internal resources in difficult conditions. Focusing on psychological and emotional processes to eliminate the negative effects of employees' feelings of burnout is considered as a solution to increase organizational performance (Maslach et al., 2001).

Positive psychology, which is an area of psychology, has come to the fore in order to solve the problems of individuals who face the negative consequences of burnout due to many reasons such as failure, intense workload, and weary dual relationships. With the positive psychology approach, it has been thought that the negative emotional states that individuals are experiencing can be turned into a positive direction (Luthans and Youssef, 2007). Based on this view, individuals who 
constantly feel negative, affects the organization as a whole. However, acting in line with the suggestions of positive psychology enables individuals to turn negative feelings into positive ones. Empirical studies on the relationship between the psychological capital (PsyCap) and burnout of employees in different cultures also support this view (Ding et al., 2015; Luthans et al., 2010; Lopez-Nunez et al., 2020; Rehman et al., 2017). Although the relationships between employees' PsyCap and burnout levels have been analyzed in different country samples, they are not sufficient to make cross-cultural comparative evaluations. Rattrie et al. (2020) state that employees' psychological efforts and skills are partly dependent on their national culture. According to Hofstede (2001), the events, meanings and social values shared since the past affect different psychological attitudes and practices in the workplace on the basis of countries and/or cultures. In this framework, Wernsing (2014) states that it is important to examine the nature of PsyCap nationally and crossculturally and to apply the original findings obtained effectively both in management theories and scientific studies also in organizations around the world. On the other hand, Schaufeli (2017) emphasizes that although the concept of burnout has become widespread, no research has been conducted that takes into account cultural differences between countries. In summary, while culture-specific meanings of the relationship between PsyCap and burnout can be studied, the organizational effects and performance implications of these two important variables at the crosscultural level should be examined. Therefore, the general impact sizes of the relationship between PsyCap and burnout in today's global structure should be determined in terms of cultures and regions.

The meta-analysis method, which is a quantitative research synthesis method, is used in estimating the general effect size in the universe by combining various effect sizes of different samples (Field and Gillett, 2010). In the literature, meta-analyses have been conducted that deal with the PsyCap or burnout levels of the employees with different variables. For instance, Avey et al. (2011) conducted a meta-analysis study that handled 51 independent studies. According to the findings obtained from this study, it was determined that there is a significant positive relationship between PsyCap and desired organizational attitudes, desired organizational behaviors, and performance. In the 
same study, it was determined that there is a significant negative relationship between PsyCap and undesired organizational attitudes and undesired organizational behaviors. In Turkey, the relationship between PsyCap and job satisfaction and performance are based on a similar meta-analysis by Tetik et al. (2018). In this study, the findings of Avey et al. (2011) were confirmed. Besides, Yorulmaz and Altınkurt (2018) performed a meta-analysis to evaluate the impact of gender, marital status, branch, school form, education, and seniority status of teachers on their burnout levels. However, no meta-analysis study was found that synthesized individual studies directly targeting two variables' subdimensions in the literature. In this context, the primary purpose of this research is to reveal the general directions and effect sizes of employees' PsyCap and burnout sub-dimensions relationship by synthesizing the studies carried out in Turkey with different samples. Thus, researchers will have the chance to compare the obtained general effect sizes with the general effect sizes existing in other cultures. The second purpose of the study is to help practitioners in Turkey by reaching a general conclusion on the relationship of employees' PsyCap and burnout subdimensions. Thereby, it will be possible to discuss the specific effects of research variables' relationship on practice indigenous to Turkey. In addition, since there are no meta-analysis results for this relationship in different cultures, the general effect sizes we will obtain as a result of our research will be compared with the results conducted in different countries. From this perspective, the study primarily includes the conceptual framework of burnout, PsyCap and its sub-dimensions. Thereafter, in line with the studies investigating the relationship between PsyCap and burnout in organizational behavior literature, hypotheses claiming a negative relationship between "PsyCap and burnout subdimensions" were developed and tested with the meta-analysis method. Finally, the analysis results have been compared with the studies from the local and foreign literature. In addition, suggestions were given for future studies and recommendations were developed. 


\section{Conceptual Framework}

\section{Burnout}

Burnout was first expressed by studies conducted on education and health sector employees (Maslach, 1976). However, diversified researches in later years have shown that similar situations are experienced in all sectors (Lemaire and Wallace, 2017). Burnout is the name given to being physically, emotionally, and mentally tired in a continuous and long-term state (Maslach and Jackson, 1981). When the concept is examined etymologically, it is seen that it has a connotation like being burned. Shakespeare (1599) used the concept of fire of love in his work "The seventh Poem of the Passionate Pilgrim" (Schaufeli, 2017). Burnout, which was the first subject of a scientific study by Freudenberger (1974), was described as a dangerous situation for working life. To explain this danger; people have positive thoughts and high career goals while participating in working life. However, things change over time, and some negative emotions such as emotional exhaustion, cynicism, and decreased professional competence cause individuals to have difficulties in business life (Maslach et al., 2001). That is why burnout; is defined as the loss of ideas, energy, and excitement (Pines and Aronson, 1988), as a negative attitude towards oneself (Katz and Kahn, 1978), and emotional destruction (Maslach, 1982) as well as physical collapse. Maslach (1976) is one of the researchers who most contributed to the current definition. According to him the concept has three dimensions which are briefly explained below.

Emotional exhaustion; is the first step of an individuals' journey to burnout. At this stage, which can be easily noticed, individuals feel themselves mentally very intense and overloaded (Maslach, 1976). According to the social exchange theory (Blau 1964), when individuals feel emotionally exhausted, their relationship with the organization becomes unstable and disordered. While this situation negatively affects performance, it may cause the individual to be exhausted under high stress due to insufficient support and loss of resources (Halbesleben and Buckley, 2004). 
Depersonalization; is the dimension of burnout whose effect can be noticed among individuals. This stage is the step after emotional exhaustion and indicates that the individual is breaking away from his ideals (Maslach, 1976). At this stage, individuals get away from their jobs and start to become indifferent to what they do. In other words, it is a defense mechanism created by individuals to avoid all negativities arising either from the excessive workload or abrasive human relationships (Leiter and Maslach, 1988). In addition, individuals tend to maintain their jobs at a minimum level in this situation, which has a negative impact on their job performance (Pearlman and Hartman, 1982). At this stage of burnout, individuals tend to extend their breaks, become unwilling to volunteer tasks and try to shorten their working hours (Maslach and Goldberg, 1998).

Decreased personal accomplishment is the third dimension. Experiencing all stages, the relationship of the individual with those around him has deteriorated and he has become insensitive to his job. This stage is the stage in which self-evaluation is made, and where negative emotions peak and self-esteem reaches its bottom (Maslach, 1976). If the gap between the requirements of the job and the individual's competencies is against the individual and is large, the individual will feel inadequate and unsuccessful (Bakker et al., 2006). Apart from merit, high workload and prolonged working hours, and limited rest hours create great stress for the individual and cause the individual to have difficulty completing his/her work in time (Schaufeli et al., 1996). This situation of the employees will make it difficult to achieve the goals.

The energy and performance of mentally tired individuals who are constantly exposed to stress will decrease with their psychological resistance (Maslach and Jackson, 1981). Negative psychological effects lead to emotional exhaustion, depersonalization, and decreased personal accomplishment (Schaufeli et al., 1996). The burnout of individuals arising from working life damages their cognitive and physical resources (Leiter and Maslach, 1988). According to the conservation of resources theory (Hobföll, 1989), individuals with personal and social resources tend to behave in the continuity and development of their resources. Employees experience stress and burnout when they perceive that the resources they obtained are under threat, lost, spent or can't be 
recovered. Apart from this, the concept of self-efficacy theory (Bandura, 1997) explains the behavior of individuals based on their existing cognitive background. Self-efficacy; refers to the individuals organizing themselves in line with their goals and managing their planned processes. In the light of the theory some individuals want to tackle a difficult task with stronger desire than their colleagues. But burnout may lead the individual away from the competitive process in his/her work life and cause organizations to have problems in obtaining a sustainable competitive advantage. Contrary to burnout, it is possible to benefit from PsyCap which can be measured, managed, and increased. Also, it is a positive organizational behavior output that directly and indirectly affect organizational performance.

\section{Positive Psychological Capital}

Although the concept of positive psychology was first expressed by Maslow, it took its current form due to Seligman's work on the subject (Luthans and Youssef, 2004). From the years when the classical management approach was adopted, the ever-increasing competitive intensity and diversifying dimensions of the competition showed that physical resources alone are insufficient to achieve sustainable competitive advantage (Luthans and Youssef, 2004). In this context, the concept of PsyCap, different from the concept of financial capital, was first expressed by Luthans and Youssef (2004). The birth of modern psychology is the result of studies on disease diagnosis and treatment. However, the science of psychology is not only concerned with the treatment of illnesses, but also with revealing and developing the strengths of people (Seligman, 1998). The concept of PsyCap was born as a result of the reinterpretation of the concept of capital, which allows the firm to continue its activities and includes its financial assets, from the perspective of psychology (Peterson and Luthans, 2003). Technological developments, adaptation speed to change and developments in the speed of accessing information have weakened the distinctive power of traditional financial capital (Luthans, Luthans, Luthans, 2004). Today, in a competitive environment, managers agree that human capital, which is also used as intellectual capital, is as important as financial capital 
(Levene, 2015). Although financial capital is strong, human capital is experienced, well-educated, talented and has a command of new ideas, there is another concept that can prevent people from being productive. This concept is called social capital (Harter et al., 2002). Social capital refers to individuals' network of relationships within and outside the organization. If the employee is supported, directed, and positively interacts in his environment, he will look to the future more optimistically.

The concept of PsyCap exists beyond social capital that covers human capital and human interactions that will manage the financial capital of the firm (Luthans et al., 2005). PsyCap focuses on revealing the potential in individuals (Levene, 2015). The way to reach productivity and high performance with a positive psychology perspective is possible by revealing the potential of individuals at the maximum level (Luthans and Youssef, 2007). Like other resources, there is also the possibility to develop and manage PsyCap (Luthans et al., 2007a; Luthans et al., 2007b). PsyCap is associated with individual productivity but is not independent of conditions such as personality traits (Gohel, 2012). It is between the traits and the contingency approaches (Luthans et al., 2010). While defining the concept, which has an important place in competitive advantage, four sub-dimensions are mentioned. These four subdimensions are; self-efficacy, optimism, hope, and resiliency. These four components interact with and make additional contributions to each other (Luthans et al., 2007a). Sub-dimensions of PsyCap;

Self-efficacy; It expresses the beliefs of individuals in meeting the requirements of the conditions that must be fulfilled to display a successful performance (Bandura, 1997). Based on the definition, it is stated that the concept of self-efficacy has a strong relationship with job performance (Stajkovic and Luthans, 1998). Bandura (1977), evaluated it as the individual's awareness of himself. It expresses the behaviors that an individual needs to display high performance and the belief that the individual own to be successful (Datu et al., 2016). The ideas of individuals about their competence also affect their cognitive development positively. In this way, the person will be able to grasp the situation and the requirements of the situation exactly and react correctly (Bandura, 1997). Self-efficacy is a long-term and extra value creating 
feature that can be developed and managed just like hope. Self-efficacy plays the role of an individual's internal manager and supervisor (Luthans et al., 2007a). With a sense of self-efficacy, individuals' determination to succeed and their performance in challenging tasks increases (Luthans et al., 2007a). Knowing what to do in the challenging parts of the task and knowing that they are competent to meet the requirements will cause the individual to be volunteer for more difficult tasks and push their own limits (Luthans et al., 2005). On the contrary, in the case of low self-efficacy, it is observed that individuals avoid volunteering for difficult tasks and are involved in practices that create simpler and smaller value within the organization (Jiang et al., 2014). According to Bandura (1997), there are four main sources where selfefficacy is fed. These are; experience resulting from striving, learning by seeing from those who know and is experienced in the social environment, strength and motivational aspect of verbal communication and psychological arousal (Bandura and Locke, 2003).

Optimism; etymologically it comes from the same origin as "best" in Latin. Optimism includes predictions for the future and it is based on the assumption that the best of what will happen will happen. Optimism is not to deny bad events (Seligman, 1998). Even in possible bad scenarios, it is to focus on the good sides. Opposite of optimism is pessimism and pessimists look at life from a more realistic perspective. When first heard, pessimism may be perceived as better than optimism, but being realistic increases risk avoidance and may make it difficult to try something new (Luthans et al., 2007a). However, optimists do not ignore the worst-case scenario, they act on the possibility of a good scenario that they can hold on to even if the worst-case scenario occurs. Seligman and Csikszentmihalyi (2000) explain optimists' interpretation systems of events and state that negative situations are dependent on external factors and are temporary. Optimists interpret good events depending on internal factors and permanently. While being optimistic affects the individual's personal development positively, it also enables the relationships with their environment to be constructive and productive (Gillham et al., 2001). Happy employees are not only stronger in their commitment to the organization but also their performance is better than others. Optimists do not suffer from absenteeism problems due to 
somatic problems or similar health problems because they are free from hopelessness and depression (Peterson, 2000). In fact, positive emotions of happy people are contagious to other people around them (Avey et al., 2008).

Hope; does not contain excuses and is explained by the theory of hope (Snyder, 2000). While it represents being willful and goal-oriented in the individual sense, it includes planning the path to the goal practically (Snyder et al., 1991). Hope theory; sometimes represents the hope to reach the goal and sometimes expresses the motivation to resist unwanted situations (Snyder, 2002). Hope can be short or long term, and it can also be a conscious or an unconscious process (Chartrand and Cheng, 2002). In previous studies, the dimension of hope; has a positive and significant relationship with job performance, job satisfaction, organizational commitment (Youssef and Luthans, 2007), profitability (Peterson and Luthans, 2003), and leadership (Luthans et al., 2005). According to the study of Thompson et al. (2015), hope creates a link between employees' independent decision-making, developing their own working methods, and feedback on engagement. Leaders' communicative and supportive attitudes affect individuals' feelings of hope. It is also stated that being clear and understandable about the task also influences feeling hopeful.

Resiliency; has the meaning of coming out of difficulties, failures, conflicts and even after good events that sometimes happens without being destroyed (Luthans and Youssef, 2004). Resiliency is not about avoiding a problematic situation and its possible destructive effect (Luthans et al., 2005). On the contrary, it expresses the will to stand up again without giving up after facing bad situations and falling. The famous Japanese motto "nana korobi ya oki" speaks exactly to this. "Fall down seven times get up eight" is based on the idea that individuals come out of every struggle by getting stronger (Windle, 2011). Individuals are affected by their duties within the organization or by the situations caused by their social environment, sometimes a short-term resiliency can have positive results that affect the future of the organization in the long term (Luthans et al., 2006). There is an opinion that this situation creates value for the organization (Luthans and Youssef, 2004). 


\section{Relationships Between PsyCap and Burnout}

The first of the four dimensions of positive PsyCap is self-efficacy. Selfefficacy expresses the self-confidence of individuals. It is when an individual sees himself/herself as competent to perform a challenging task. Emotional exhaustion, which is the first sub-dimension of burnout, refers to the individual feeling overloaded and withdrawing from activities that require intense effort as a result of the social exchange theory. In this context, the effects of the two concepts on the individual are opposite. Supporting this idea, Rehman et al. (2017) concluded in a study conducted on faculty members that self-efficacy had a negative and significant effect on emotional exhaustion. In this context, Hypothesis 1 has been expressed based on previous studies and theoretical frameworks. Depersonalization, which is the second of the three sub-dimensions of burnout; is a process that an individual experiences after the emotional exhaustion process. It is a form of defense of individuals to avoid the intense pressure and weary overload caused by their environment in working life. In studies examining the effect of self-efficacy on depersonalization, it was found that there are negative and significant relationships between the two concepts (Ding et al., 2015; Rehman et al., 2017). Hypothesis 2 has been expressed based on previous studies and theoretical frameworks on the relations between the two concepts. Decreased personal accomplishment is the final stage where the individual listens to himself and makes a decision about himself. As in other sub-dimensions, it is stated that decreased personal accomplishment dimension has a negative and significant relationship with self-efficacy (Ding et al., 2015; Rehman et al., 2017). In this context, Hypothesis 3 is expressed based on previous studies and theoretical framework.

Hypothesis 1: There is a significant negative relationship between employees' self-efficacy levels and emotional exhaustion.

Hypothesis 2: There is a significant negative relationship between employees' self-efficacy levels and depersonalization.

Hypothesis 3: There is a significant negative relationship between employees' self-efficacy levels and decreased personal accomplishment. 
Optimism has a very special place in positive psychology. Optimists believe that what happens to them is good for them and this increases their determination to work. Lurthans and Youssef (2004) state that optimists associate negative events with external situations and evaluate them as a temporary, short process. However, positive events arise from intrinsic and personal competencies. On the other hand, the emotional exhaustion dimension of burnout refers to the individual feeling emotionally exhausted and worn out (Schulman, 1995). When people become depersonalized, they lose interest in the events happening around them. Contrarily, individuals with decreased personal accomplishment lose their self-confidence and belief in their competencies (Marann et al., 2013). Considering the positive effects of optimism on people and the negative effects of each of the dimensions of burnout on people, it is expected that the relationships between optimism and burnout will be in the opposite direction. Based on this view, previous studies in different countries have been examined. Rehman et al. (2017) and Ding et al. (2015) found a significant negative relationship between optimism and emotional exhaustion. Similarly, a negative and significant relationship was found in the study conducted on different business groups in Spain (Lopez-Nunez et al., 2020). Hypothesis-4 was created based on the data obtained from the mentioned studies and the theoretical framework. Relationships between optimism and depersonalization dimension were examined. In the study of Ding et al. (2015), they found a negative and significant relationship between optimism and depersonalization. Similarly, the study conducted by Rehman et al. (2017) and the study of Lopez-Nunez et al. (2020) found negative relations. Hypothesis 5 was formed based on these findings and theoretical framework. In the decreased personal accomplishment phase, which is the last dimension of burnout, individuals are unwilling to take on difficult tasks and have lost their motivation to work. Thus, a decrease in personal accomplishment represents a situation that conflicts with the optimism dimension of positive PsyCap. Previous studies were examined and different results were found. Rehman et al. (2017) and Lopez-Nunez et al. (2020), found a positive and significant relationship, while Ding et al. (2015) found a negative and significant relationship. In the same study, it was 
concluded that optimism negatively and significantly affected decreased personal accomplishment. Hypothesis 6 was created based on previous studies and theoretical framework.

Hypothesis 4: There is a negative and significant relationship between employees' optimism and emotional exhaustion.

Hypothesis 5: There is a negative and significant relationship between employees' optimism and depersonalization.

Hypothesis 6: There is a negative and significant relationship between employee optimism and decreased personal accomplishment.

Hope, another sub-dimension of Positive PsyCap, expresses a threefactor motivation state expressed by Rick Snyder (1994). These factors are; goals, actions, and methods. Hoping, which encompasses using all means with a willingness and strong belief towards the goals, contains contrasts with emotional exhaustion. On the other hand, when the previous studies are examined; Lopez-Nunez et al. (2020), Rehman et al. (2017) and Ding et al. (2015) found a negative and significant relationship between the hope dimension and emotional exhaustion. Hypothesis 7 was created based on previous studies and theoretical framework. In the process of depersonalization, which is the second dimension of burnout, the individual loses his interest in his environment and his determination and motivation for his work. In this way, an opposite emotional state of hoping is created. In this context, Lopez-Nunez et al. (2020), Ding et al. (2015) and Rehman et al. (2017), found a negative and significant relationship in their studies. For this reason, based on previous studies and theory, Hypothesis 8 was created. In studies examining the relationship between decreased personal accomplishment and hope dimension, conflicting results have been obtained. So much so that the direction and severity of the relations between these two concepts differ. For instance, Ding et al. (2015) concluded in their study that there is a negative and significant relationship between hope and decreased personal accomplishment. However, Rehman et al. (2017) and Lopez-Nunez et al. (2020), found a positive and significant relationship between hope and decreased personal accomplishment in their studies. Hypothesis 9 was created based on the theoretical framework and results of studies carried out at different time intervals, geographies, and sectors. 
Hypothesis 7: There is a significant negative relationship between employees' hope levels and emotional exhaustion.

Hypothesis 8: There is a significant negative relationship between employees' hope levels and depersonalization.

Hypothesis 9: There is a significant negative relationship between employees' hope levels and decreased personal accomplishment.

Resiliency is the final dimension of positive PsyCap. Shortly, it refers to the ability of individuals to stand up and move forward after the negative situations they have experienced. The relationships between resiliency, which are related to adaptability and strength, and all dimensions of burnout were examined. Looking at previous studies, Ding et al. (2015), Rehman et al. (2017) and Lopez-Nunez et al. (2020) found a negative and significant relationship between resiliency and emotional exhaustion in their studies. Thus, Hypothesis 10 has been formed based on previous studies and theoretical framework. Previous studies were examined to understand the relationship between resiliency and depersonalization. When previous studies were examined to understand the relationship between resilience and depersonalization, a negative and significant relationship was found between the two variables for Chinese nurses (Ding et. al., 2015). However, no significant relationship was found between variables in the other two studies examined (Lopez-Nunez et al., 2020; Rehman et al., 2017). In this context, Hypothesis 11 was formed based on the different findings of studies and theoretical framework. Previous studies were examined to understand the relationship between decreased personal accomplishment and resiliency. In the study of Ding et. al. (2015) it was found that there is a negative and significant relationship resiliency and depersonalization. However, positive and significant relationships between resiliency and depersonalization were found in the studies of Rehman et al.(2017) and Lopez-Nunez et al. (2020). In this context, Hypothesis 12 was formed based on the findings and theoretical framework.

Hypothesis 10: There is a negative and significant relationship between employees' resiliency and emotional exhaustion.

Hypothesis 11: There is a negative and significant relationship between workers' resiliency and depersonalization. 
Hypothesis 12: There is a negative and significant relationship between the resiliency levels of the employees and the decreased personal accomplishment.

\section{Method}

In our study, meta-analysis, which is a quantitative research synthesis method, was used. Meta-analysis generally consists of several stages. These are (Field and Gillett, 2010).

- Literature review,

- Determination and application of inclusion criteria in the analysis (Coding),

- Calculation of impact sizes of individual studies,

- Performing basic meta-analysis and calculating the general effect size,

- Predicting publication bias,

- Correction of publication bias,

- Reporting.

Following the literature review conducted within our research scope, studies that met the criteria presented below were included in the metaanalysis. These criteria are:

- Studies conducted on a Turkish sample and written in English or Turkish,

- Providing the first criterion all completed Ph.D. dissertations, master's thesis, articles and proceedings [Published proceedings of Organizational Behavior (Published since 2013), Management and Organization Congresses which are held every year in Turkey] from the beginning of 2012 to the end of August 2020,

- In the scope of the first two criteria containing Pearson correlation coefficients and sample size values of main research variables or subdimensions.

Within the scope of these specified criteria, Google, Yandex search engines, the Higher Education Council Thesis Center of Turkey and electronic databases were searched using "Psychological Capital", "Burnout" or both variables and sub-dimensions as keywords. In addition, the proceedings of Management and Organization Congresses 
since 2012 and Organizational Behavior Congresses since 2013 were examined. As a result of the search, all the studies were recorded in an Excel sheet (including title, author, year, type, scales, sample size and correlation values). Later, some of the dissertations, theses, articles and proceedings were eliminated because they did not contain the correlation and sample size values required for the meta-analysis. In order to avoid the nonindependence problem emphasized by Rosenthal and DiMatteo (2001) the same results obtained in dissertations, theses, articles or papers from the same results were not included in the analysis as a second or more. As a result of evaluations, 9 studies (5 theses and 4 articles) reporting the relationships between the main research variables' sub-dimensions met all criteria previously stated. These studies and reported correlation coefficients are illustrated in Table 1, 2, 3, 4 .

Table 1. Studies included in the meta-analysis on the relationship between selfefficacy and depersonalization, emotional exhaustion, decreased personal accomplishment

\begin{tabular}{llll}
\hline Authors of the Study & $\begin{array}{l}\text { Self Efficacy- } \\
\text { Depersonalization }\end{array}$ & $\begin{array}{l}\text { Self Efficacy- } \\
\text { Emotional } \\
\text { Exhaustion }\end{array}$ & $\begin{array}{l}\text { Self Efficacy- } \\
\text { Decreased Personal } \\
\text { Accomplishment }\end{array}$ \\
\hline Altınkurt, Y., Ertürk, A. and Yılmaz, İ. (2015) & -0.410 & -0.250 & -0.310 \\
Argon, T. and Tükel, H. (2016) & -0.347 & -0.374 & -0.525 \\
Tokmak, M. (2018) & -0.038 & -0.307 & -0.391 \\
Enderoğlu, E. G. (2018) & -0.270 & -0.360 & -0.450 \\
Söylemez, M. (2019) & -0.078 & -0.118 & -0.627 \\
Yılmaz, M. (2019) & -0.363 & -0.294 & -0.519 \\
Hamuluoğlu, B. (2019) & -0.182 & -0.230 & 0.547 \\
El, İ. (2019) & -0.300 & -0.400 & -0.330 \\
Kapusuz A. G. and Çavuş, M. F. (2019) & -0.680 & -0.510 & 0.043 \\
TOTAL SAMPLE SIZE & $\mathbf{2 2 8 0}$ & & \\
\hline
\end{tabular}

Table 2. Studies included in the meta-analysis on the relationship between optimism and depersonalization, emotional exhaustion, decreased personal accomplishment

\begin{tabular}{|c|c|c|c|}
\hline Authors of the Study & $\begin{array}{l}\text { Optimism- } \\
\text { Depersonali } \\
\text { zation }\end{array}$ & $\begin{array}{l}\text { Optimism- } \\
\text { Emotional } \\
\text { Exhaustion }\end{array}$ & $\begin{array}{l}\text { Optimism- } \\
\text { Decreased Personal } \\
\text { Accomplishment }\end{array}$ \\
\hline Argon, T. and Tükel, H. (2016) & -0.221 & -0.449 & -0.376 \\
\hline Tokmak, M. (2018) & -0.205 & -0.543 & -0.184 \\
\hline Yilmaz, M. (2019) & -0.365 & -0.532 & -0.502 \\
\hline Hamuluoğlu, B. (2019) & -0.461 & -0.495 & 0.506 \\
\hline El, İ. (2019) & -0.340 & -0.400 & -0.060 \\
\hline Kapusuz A. G. and Çavuş, M. F. (2019) & -0.620 & -0.501 & 0.061 \\
\hline TOTAL SAMPLE SIZE & 2280 & & \\
\hline
\end{tabular}


Table 3. Studies included in the meta-analysis on the relationship between hope and depersonalization, emotional exhaustion, decreased personal accomplishment

\begin{tabular}{llll}
\hline Authors of the Study & Hope- Depersonalization & $\begin{array}{l}\text { Hope- Emotional } \\
\text { Exhaustion }\end{array}$ & $\begin{array}{l}\text { Hope- Decreased Personal } \\
\text { Accomplishment }\end{array}$ \\
\hline Altınkurt, Y., Ertürk, A. and & -0.400 & -0.230 & -0.410 \\
Yılmaz, İ. (2015) & -0.273 & -0.553 & -0.547 \\
Argon, T. and Tükel, H. (2016) & -0.061 & -0.406 & -0.277 \\
Tokmak, M. (2018) & -0.230 & -0.380 & -0.410 \\
Enderoğlu, E. G. (2018) & -0.340 & -0.432 & -0.168 \\
Söylemez, M. (2019) & -0.286 & -0.363 & -0.534 \\
Yılmaz, M. (2019) & -0.309 & -0.308 & 0.602 \\
Hamuluoğlu, B. (2019) & -0.420 & -0.510 & -0.300 \\
El, İ. (2019) & -0.531 & 0.089 \\
Kapusuz A. G. and Çavuş, M. & -0.671 & & \\
F. (2019) & $\mathbf{2 2 8 0}$ & & \\
TOTAL SAMPLE SIZE & &
\end{tabular}

Tablo 4. Studies included in the meta-analysis on the relationship between resiliency and depersonalization, emotional exhaustion, decreased personal accomplishment

\begin{tabular}{llll}
\hline Authors of the Study & $\begin{array}{l}\text { Resiliency - } \\
\text { Depersonalization }\end{array}$ & $\begin{array}{l}\text { Resiliency - } \\
\text { Emotional } \\
\text { Exhaustion }\end{array}$ & $\begin{array}{l}\text { Resiliency - } \\
\text { Decreased } \\
\text { Personal } \\
\text { Accomplishment }\end{array}$ \\
\hline Altınkurt, Y., Ertürk, A. and & -0.390 & -0.230 & -0.380 \\
Yilmaz, İ. (2015) & -0.326 & -0.517 & -0.467 \\
Argon, T. and Tükel, H. (2016) & -0.088 & -0.346 & -0.272 \\
Tokmak, M. (2018) & -0.007 & -0.013 & 0.140 \\
Enderoğlu, E. G. (2018) & -0.078 & -0.118 & -0.627 \\
Söylemez, M. (2019) & -0.262 & -0.288 & -0.580 \\
Yllmaz, M. (2019) & -0.207 & -0.267 & 0.563 \\
Hamuluoğlu, B. (2019) & -0.370 & -0.490 & -0.450 \\
El, İ. (2019) & -0.668 & -0.529 & 0.039 \\
Kapusuz A. G. and Çavuş, M. F. & & & \\
(2019) & $\mathbf{2 2 8 0}$ & & \\
TOTAL SAMPLE SIZE & &
\end{tabular}

All studies in Table 1, 2, 3 and 4 are carried out in organizations operating in the public or private sectors in Turkey. The total sample size of these 9 studies is 2280 employees. According to the 2020 years' statistics of the Turkish Statistical Institute 30 million employees are working in public and private sectors in Turkey. Considering the reliability of 0.95 and 0.05 sampling error, it was determined that a sample of 384 people could represent this universe as a result of the calculations made with the formula Bartlett et al. (2001). Based on this, it 
was evaluated that the research sample $(5835>384)$ is sufficient to represent employees in Turkey. Comprehensive Meta-Analysis (CMA) V3 (trial) software was used to perform the remaining stages of metaanalysis.

\section{Findings}

Initially, Pearson correlation coefficients of each study included in the meta-analysis were transformed into Fisher-Z statistics via CMA V3. This statistic is the best solution for combining the significance of the results of different studies (Bakioğlu and Özcan, 2016). The next step after calculating the effect sizes of individual studies is to calculate the general effect size. Two models based on different assumptions are used to calculate the general effect size. These are fixed effect models and random effect models (Hunter and Schmidt, 2000). Homogeneity test has been performed to decide which model to use (Hunter and Schmidt, 2000). In the homogeneity test, the $Q$ value is calculated for the degree of freedom (Studies included in the analysis -1) and $\mathrm{p}$ value (For heterogeneity, it must be significant). If the calculated $Q$ value is greater than the value in the Chi-square $\left(\chi^{2}\right)$ table, it is decided that it is heterogeneous. In this case, a random effect model is used. The homogeneity test in CMA V3 is based on Q statistics. CMA calculates the general effect size within a confidence interval according to both the fixed effect and the random effect model. In the light of this information, the program was run and the $Q$ value used in the homogeneity test was calculated, which allows us to decide which model to use, as well as calculating the general effect size of fixed and random effect models. The results of the homogeneity test with general effect sizes according to fixed and random effect models are illustrated in Table 5.

After running the program, $Q$ values (Degree of freedom $=8, p<0.05$ ) were calculated for each relationship. The corresponding value in the $\left(\chi^{2}\right)$ table is 15,507 . Since all calculated $Q$ values are higher than 15.507 , it was decided that the studies included in the analyses were heterogeneous. For this reason, the random effect model was used and the general effect size for each relationship between PsyCap and burnout sub-dimensions 
was calculated. Cohen et al. (2007) interpret effect sizes based on correlation coefficients as follows:

- Between 0.00 and 0.10 very weak,

- Between 0.10 and 0.30 weak,

- Between 0.30 and 0.50 medium,

- Between 0.50 and 0.80 high,

- Above 0.80 very high.

Table 5. Results of homogeneity test with general effect sizes of fixed and random effect models for all relations between PsyCap and Burnout dimensions

\begin{tabular}{|c|c|c|c|c|c|c|c|c|}
\hline & \multicolumn{4}{|c|}{ Effect Size and $\% 95$ Confidence Interval } & \multicolumn{4}{|c|}{ Homogeneity } \\
\hline & Model & $\begin{array}{l}\text { Point } \\
\text { Estimate }\end{array}$ & $\begin{array}{l}\text { Number } \\
\text { Studies }\end{array}$ & $\begin{array}{l}\text { Lower } \\
\text { Limit }\end{array}$ & $\begin{array}{l}\text { Upper } \\
\text { Limit }\end{array}$ & $\begin{array}{l}\mathrm{Q} \\
\text { Value }\end{array}$ & $\begin{array}{l}\text { df } \\
(Q)\end{array}$ & $\begin{array}{l}\mathbf{P} \\
\text { Value }\end{array}$ \\
\hline \multirow{2}{*}{$\begin{array}{l}\text { Self Efficacy- } \\
\text { Depersonalization }\end{array}$} & Fixed & -0.345 & 9 & -0.381 & -0.308 & \multirow{2}{*}{148.129} & \multirow{2}{*}{8} & \multirow{2}{*}{0.000} \\
\hline & Random & -0.312 & 9 & -0.465 & -0.142 & & & \\
\hline \multirow{2}{*}{$\begin{array}{l}\text { Self Efficacy- } \\
\text { Emotional } \\
\text { Exhaustion }\end{array}$} & Fixed & -0.337 & 9 & -0.373 & -0.300 & \multirow[b]{2}{*}{38.283} & \multirow[b]{2}{*}{8} & \multirow[b]{2}{*}{0.000} \\
\hline & Random & -0.321 & 9 & -0.402 & -0.236 & & & \\
\hline \multirow{2}{*}{$\begin{array}{l}\text { Self Efficacy- } \\
\text { Decreased Personal } \\
\text { Accomplishment }\end{array}$} & Fixed & -0.253 & 9 & -0.291 & -0.214 & \multirow[b]{2}{*}{315.675} & \multirow[b]{2}{*}{8} & \multirow[b]{2}{*}{0.000} \\
\hline & Random & -0.300 & 9 & -0.516 & -0.047 & & & \\
\hline \multirow{2}{*}{$\begin{array}{l}\text { Optimism- } \\
\text { Depersonalization }\end{array}$} & Fixed & -0.353 & 9 & -0.353 & -0.388 & \multirow{2}{*}{99.722} & \multirow{2}{*}{8} & \multirow{2}{*}{0.000} \\
\hline & Random & -0.304 & 9 & -0.304 & -0.432 & & & \\
\hline \multirow{2}{*}{$\begin{array}{l}\text { Optimism- } \\
\text { Emotional } \\
\text { Exhaustion }\end{array}$} & Fixed & -0.400 & 9 & -0.434 & -0.364 & \multirow[b]{2}{*}{89.340} & \multirow[b]{2}{*}{8} & \multirow[b]{2}{*}{0.000} \\
\hline & Random & -0.381 & 9 & -0.494 & -0.255 & & & \\
\hline \multirow{2}{*}{$\begin{array}{l}\text { Optimism- } \\
\text { Decreased Personal } \\
\text { Accomplishment }\end{array}$} & Fixed & -0.106 & 9 & -0.146 & -0.065 & \multirow[b]{2}{*}{204.081} & \multirow[b]{2}{*}{8} & \multirow[b]{2}{*}{0.000} \\
\hline & Random & -0.117 & 9 & -0.318 & 0.093 & & & \\
\hline \multirow{2}{*}{$\begin{array}{l}\text { Hope- } \\
\text { Depersonalization }\end{array}$} & Fixed & -0.383 & 9 & -0.418 & -0.347 & \multirow{2}{*}{114.366} & \multirow{2}{*}{8} & \multirow{2}{*}{0.000} \\
\hline & Random & -0.347 & 9 & -0.478 & -0.201 & & & \\
\hline \multirow{2}{*}{$\begin{array}{l}\text { Hope- Emotional } \\
\text { Exhaustion }\end{array}$} & Fixed & -0.423 & 9 & -0.456 & -0.389 & \multirow{2}{*}{35.189} & & \\
\hline & Random & -0.417 & 9 & -0.488 & -0.341 & & 8 & 0.000 \\
\hline Hope- Decreased & Fixed & -0.182 & 9 & -0.222 & -0.142 & & & \\
\hline $\begin{array}{l}\text { Personal } \\
\text { Accomplishment }\end{array}$ & Random & -0.223 & 9 & -0.452 & 0.033 & 309.507 & 8 & 0.000 \\
\hline Resiliency - & Fixed & -0.336 & 9 & -0.372 & -0.299 & & & \\
\hline Depersonalization & Random & -0.284 & 9 & -0.437 & -0.116 & 141.408 & 8 & 0.000 \\
\hline Resiliency - & Fixed & -0.356 & 9 & -0.392 & -0.320 & & & \\
\hline $\begin{array}{l}\text { Emotional } \\
\text { Exhaustion }\end{array}$ & Random & -0.325 & 9 & -0.431 & -0.211 & 69.231 & 8 & 0.000 \\
\hline Resiliency - & Fixed & -0.243 & 9 & -0.282 & -0.204 & & & \\
\hline $\begin{array}{l}\text { Decreased Personal } \\
\text { Accomplishment }\end{array}$ & Random & -0.246 & 9 & -0.486 & 0.029 & 358.71 & 8 & 0.000 \\
\hline
\end{tabular}


Within the scope of computed general effect sizes of 9 studies it was found out that between employees' PsyCap and burnout sub-dimensions are medium (Self Efficacy-Depersonalization=-0.312, Self-EfficacyEmotional Exhaustion=-0.321, Self-Efficacy-Decreased Personal Accomplishment $=-0.300, \quad$ Optimism-Depersonalization $=-0.304$, Optimism-Emotional Exhaustion=-0.381, Hope-Depersonalization=0.347, Hope-Emotional Exhaustion=-0.417, Resiliency - Emotional Exhaustion=-0.325) and low level (Optimism-Decreased Personal Accomplishment=-0.117, Hope-Decreased Personal Accomplishment=0.223, Resiliency-Depersonalization=-0.284, Resiliency-Decreased Personal Accomplishment $=-0.246$ ) negative correlations. Within the scope of computed general effect sizes H1, H2, H3, H4, H5, H6, H7, H8 and $\mathrm{H} 9$ hypotheses were accepted.

After the effect sizes were calculated, the validity of the meta-analyses were checked. This situation called publication bias occurs when the studies included in the research misrepresent the universe. It usually emerges from two reasons. The first is called the file drawer problem and occurs because of the tendency not including statistically insignificant results in the analysis (Field and Gillett, 2010). The second one is the nonindependence problem and stems from including the same results twice or more in the analysis (Rosenthal and DiMatteo, 2001). In this context, the Tau coefficients, fail-safe numbers and funnel plots were examined. For the validity, of the meta-analysis it is expected that the Tau coefficient will be close to 1.00 and the two-tailed p-value is more than ( $p>0.05$ ) the significance level (Begg and Mazumdar, 1994; Dinçer, 2014). Tau coefficient statistics are illustrated in Table 6.

Table 6. Publication bias statistics of individual studies (Tau Coefficient)

\begin{tabular}{|c|c|c|c|c|c|c|c|c|c|c|c|c|}
\hline & 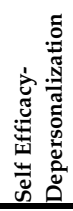 & 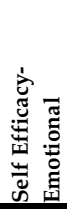 & 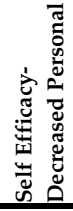 & 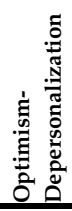 & 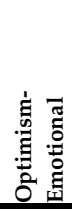 & 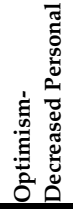 & 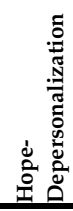 & 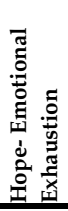 & 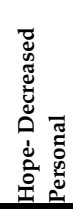 & 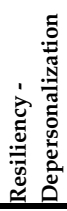 & 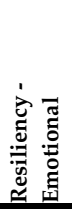 & 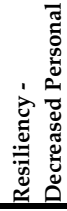 \\
\hline $\begin{array}{l}\text { Kendall's Tau } \\
\text { without continuity } \\
\text { correction }\end{array}$ & .22 & .38 & -.28 & .44 & .33 & -.11 & .39 & .22 & -.22 & .39 & .56 & -.11 \\
\hline P value (2-tailed) & .40 & .14 & .30 & .10 & .21 & .68 & .14 & .40 & .40 & .14 & .05 & .68 \\
\hline
\end{tabular}


As a result of the analyses performed in CMA V3, it was seen that the Tau coefficients were minimum -0.11 and maximum 0.56 and all twotailed p-value was over 0.05. Another method is Rosenthal's (1979) failsafe number. In this method, the number of studies required to transform general effect size obtained from the combined test into insignificant is calculated. If this calculated value is considerably higher than the number of studies included in the analysis, it is assumed that the results are resistant to publication bias. The fail-safe number calculation results are illustrated in Table 7.

Table 7. Rosenthal's fail-safe number calculation results

\begin{tabular}{|c|c|c|c|}
\hline & $\begin{array}{l}\text { Number of } \\
\text { Observed } \\
\text { Studies }\end{array}$ & $\begin{array}{l}\text { Number of Missing } \\
\text { Studies that would } \\
\text { Bring p value>alpha } \\
\text { (Fail Safe Number) }\end{array}$ & $\begin{array}{l}\text { P-Value for } \\
\text { Observed } \\
\text { Studies }\end{array}$ \\
\hline $\begin{array}{l}\text { Self Efficacy- } \\
\text { Depersonalization }\end{array}$ & 9 & 575 & 0.0000 \\
\hline $\begin{array}{l}\text { Self Efficacy- Emotional } \\
\text { Exhaustion }\end{array}$ & 9 & 575 & 0.0000 \\
\hline $\begin{array}{l}\text { Self Efficacy- Decreased } \\
\text { Personal Accomplishment }\end{array}$ & 9 & 397 & 0.0000 \\
\hline Optimism- Depersonalization & 9 & 577 & 0.0000 \\
\hline $\begin{array}{l}\text { Optimism- Emotional } \\
\text { Exhaustion }\end{array}$ & 9 & 850 & 0.0000 \\
\hline $\begin{array}{l}\text { Optimism- Decreased Personal } \\
\text { Accomplishment }\end{array}$ & 9 & 56 & 0.0000 \\
\hline Hope- Depersonalization & 9 & 726 & 0.0000 \\
\hline Hope- Emotional Exhaustion & 9 & 1002 & 0.0000 \\
\hline $\begin{array}{l}\text { Hope- Decreased Personal } \\
\text { Accomplishment }\end{array}$ & 9 & 202 & 0.0000 \\
\hline Resiliency- Depersonalization & 9 & 507 & 0.0000 \\
\hline $\begin{array}{l}\text { Resiliency- Emotional } \\
\text { Exhaustion }\end{array}$ & 9 & 621 & 0.0000 \\
\hline $\begin{array}{l}\text { Resiliency- Decreased Personal } \\
\text { Accomplishment }\end{array}$ & 9 & 312 & 0.0000 \\
\hline
\end{tabular}

As seen in Table 7, according to the calculated Rosenthal's fail-safe number, minimum 56 and maximum 1002 studies with opposite values should be included in the analysis in order to turn the calculated general effect sizes for PsyCap and burnout sub-dimensions' relationship to insignificant. The computed fail-safe numbers are considerably higher 
than the number of 9 studies included in the current analyses anyway. Therefore, all the results of this study was evaluated to be quite resistant to publication bias.

Another way to evaluate publication bias is to examine the funnel plots. The funnel plot is a simple intersecting scatter plot of the effect size estimated in each study with the sample size of these studies. Y-axis shows the sample size, variance and standard error. Results from studies with a small sample are scattered over a large area at the bottom of the graphic, while studies with a large sample show a smaller distribution on the top. If there is a publication bias, the funnel plot will show a skewed and asymmetric distribution (Borenstein et al., 2009). All the Funnel Plots showing PsyCap and burnout sub-dimensions' relationships are illustrated in Figure 1.

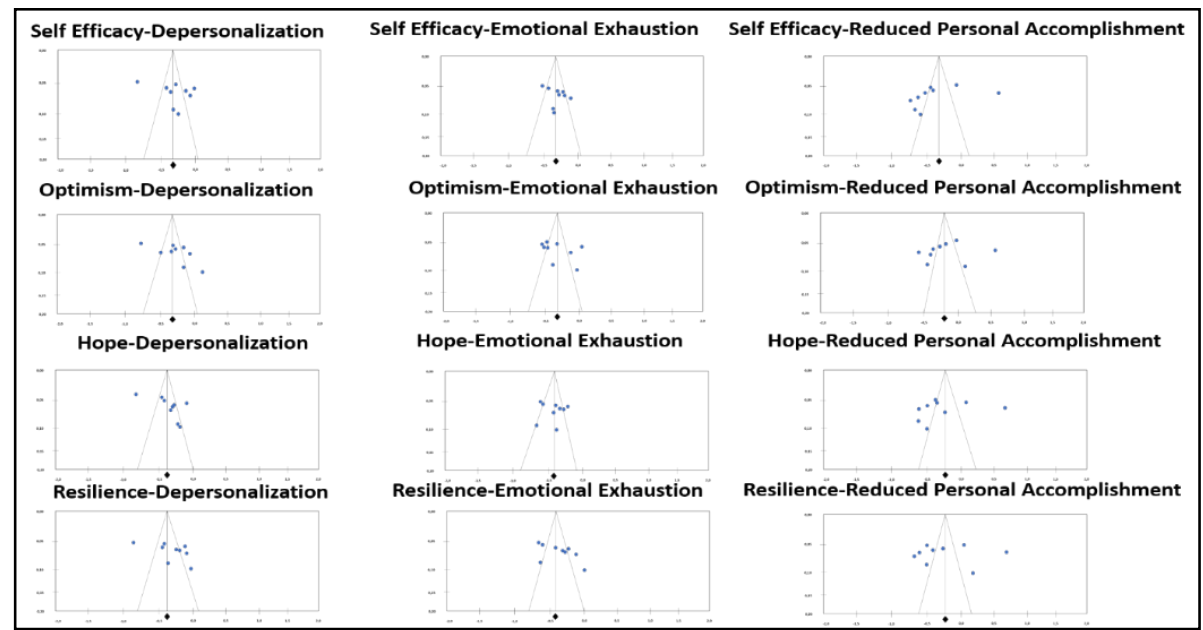

Figure 1. The Funnel Plots showing the distribution of effect sizes according to the sample sizes of each study

As a result of the examination of the funnel plots, it was evaluated that the studies included in the analyses of the relationships between PsyCap and burnout sub-dimensions, were generally symmetrically distributed around the $\mathrm{Y}$ axis. In the light of all these findings, it was concluded that the meta-analyses performed were valid and there were no publication biases. 


\section{Discussion}

In this study, a meta-analysis was conducted to synthesize the studies conducted between 2012-2020 in Turkey on the relationship between PsyCap of employees and burnout sub-dimensions. 9 studies were included in the analysis, with a sample size of 2280 public and private sector employees within the scope of the criteria determined at the beginning. Analyzes were performed with CMA V3 software. The random-effect model was used in the analyzes and the general effect sizes varied negatively between medium and weak level. The validity of the meta-analysis was assessed through Tau coefficients, fail-safe numbers and funnel plots. As a result of these assessments it was determined that there is no publication bias.

These results obtained from Turkey generally overlap with individual studies conducted in different cultures in the literature (Amornpipat, 2019; Ding et al., 2015; Virga et al., 2020). But in some studies (LopezNunez et al., 2020; Oles, 2017; Rehman et al., 2017) conducted in different dates and countries, findings that differ from the results of our study were also reached. These differences are presented in Table 8.

Ding et al. (2015) found negative relationships between PsyCap and all sub-dimensions of burnout in a study conducted on 1496 Chinese nurses. However, the severity of the relationship between self-efficacy, hope, and optimism with emotional exhaustion and depersonalization was found differently. The effect, which is medium in Turkey, has been found to be weak in this study. In addition, the level of correlation between resiliency and emotional exhaustion was medium in Turkey, while it was found to be weak in this study.

In the study of Rehman et al. (2017), the number of differences increases which is conducted on 282 academicians working in 17 technical institutes in Pakistan. All relationships except the relationship between optimism, hope, resiliency, and emotional exhaustion and the relationship between optimism and depersonalization were found different from the Turkey sample. In fact, in the study in Pakistan, a positive relationship was found between optimism, hope, resiliency and decreased personal accomplishment. 
Table 8. Correlation coefficients of individual studies investigating the relationship between PsyCap and burnout sub-dimensions

\begin{tabular}{|c|c|c|c|c|c|c|c|}
\hline & & $\begin{array}{l}\text { Turkey } \\
(2012- \\
2020)\end{array}$ & $\begin{array}{l}\text { China } \\
2015 \\
\text { (Ding et } \\
\text { al., 2015) }\end{array}$ & $\begin{array}{l}\text { Pakistan } \\
2017 \\
\text { (Rehman et } \\
\text { al., 2017) }\end{array}$ & $\begin{array}{l}\text { Thailand } \\
2019 \\
\text { (Amornp } \\
\text { ipat., } \\
\text { 2019) }\end{array}$ & $\begin{array}{l}\text { Romania } \\
2020 \\
\text { (Virga et } \\
\text { al., 2020) }\end{array}$ & $\begin{array}{l}\text { Spain } \\
2020 \\
\text { (Lopez- } \\
\text { Nunez et } \\
\text { al., 2020) }\end{array}$ \\
\hline \multirow[t]{3}{*}{$\begin{array}{l}\text { Self- } \\
\text { efficacy }\end{array}$} & $\begin{array}{l}\text { Emotional } \\
\text { Exhaustion }\end{array}$ & $\mathrm{r}=-0.321^{*}$ & $\mathrm{r}=-0.100^{* *}$ & $\mathrm{r}=-0.294^{* * *}$ & $\mathrm{r}=-0.22^{* *}$ & $\mathrm{r}=-0.36^{* *}$ & $\mathrm{r}=-0.27^{* *}$ \\
\hline & $\begin{array}{l}\text { Depersonal } \\
\text { ization }\end{array}$ & $\mathrm{r}=-0.312^{*}$ & $\mathrm{r}=-0.183^{* *}$ & $\mathrm{r}=-0.226^{* *}$ & $\mathrm{r}=-0.04^{*}$ & $\mathrm{r}=-0.51^{* *}$ & $r=-0.16^{* *}$ \\
\hline & $\begin{array}{l}\text { Decreased } \\
\text { Personal } \\
\text { Accomplis } \\
\text { hment }\end{array}$ & $\mathrm{r}=-0.300^{*}$ & $\mathrm{r}=-0.318^{* *}$ & $\mathrm{r}=-0.065^{*}$ & $\mathrm{r}=-0.25^{* *}$ & - & $\mathrm{r}=0.29^{* *}$ \\
\hline \multirow[t]{3}{*}{ Optimism } & $\begin{array}{l}\text { Emotional } \\
\text { Exhaustion }\end{array}$ & $\mathrm{r}=-0.381^{*}$ & $\mathrm{r}=-0.184^{* *}$ & $\mathrm{r}=-0.508^{* *}$ & $r=-0.36^{* *}$ & $\mathrm{r}=-0.53^{* *}$ & $\mathrm{r}=-0.41^{* *}$ \\
\hline & $\begin{array}{l}\text { Depersonal } \\
\text { ization }\end{array}$ & $r=-0.304^{*}$ & $\mathrm{r}=-0.252^{* *}$ & $\mathrm{r}=-0.401^{* *}$ & $\mathrm{r}=-0.24^{* *}$ & $\mathrm{r}=-0.66^{* *}$ & $\mathrm{r}=-0.19^{* *}$ \\
\hline & $\begin{array}{l}\text { Decreased } \\
\text { Personal } \\
\text { Accomplis } \\
\text { hment }\end{array}$ & $\mathrm{r}=-0.117^{*}$ & $\mathrm{r}=-0.222^{* *}$ & $\mathrm{r}=0.234^{* *}$ & $\mathrm{r}=-0.39^{* *}$ & - & $\mathrm{r}=0.39^{* *}$ \\
\hline \multirow[t]{3}{*}{ Hope } & $\begin{array}{l}\text { Emotional } \\
\text { Exhaustion }\end{array}$ & $\mathrm{r}=-0.417^{*}$ & $\mathrm{r}=-0.214^{* *}$ & $\mathrm{r}=-0.323^{* *}$ & $\mathrm{r}=-0.36^{* *}$ & $\mathrm{r}=-0.44^{* *}$ & $\mathrm{r}=-0.32^{* *}$ \\
\hline & $\begin{array}{l}\text { Depersonal } \\
\text { ization }\end{array}$ & $\mathrm{r}=-0.347^{*}$ & $\mathrm{r}=-0.184^{* *}$ & $\mathrm{r}=-0.197^{* *}$ & $r=-0.16^{* *}$ & $r=-0.59^{* *}$ & $\mathrm{r}=-0.19^{* *}$ \\
\hline & $\begin{array}{l}\text { Decreased } \\
\text { Personal } \\
\text { Accomplis } \\
\text { hment }\end{array}$ & $r=-0.223^{*}$ & $\mathrm{r}=-0.235^{* *}$ & $\mathrm{r}=0.406^{*}$ & $r=-0.36^{* *}$ & - & $\mathrm{r}=0.51^{* *}$ \\
\hline \multirow[t]{3}{*}{ Resiliency } & $\begin{array}{l}\text { Emotional } \\
\text { Exhaustion }\end{array}$ & $\mathrm{r}=-0.325^{*}$ & $\mathrm{r}=-0.190^{* *}$ & $\mathrm{r}=-0.319^{* *}$ & $\mathrm{r}=-0.30^{* *}$ & $\mathrm{r}=-0.34^{* *}$ & $r=-0.16^{* *}$ \\
\hline & $\begin{array}{l}\text { Depersonal } \\
\text { ization }\end{array}$ & $r=-0.284^{*}$ & $\mathrm{r}=-0.204^{* *}$ & $\mathrm{r}=-0.207$ & $\mathrm{r}=-0.23^{* *}$ & $\mathrm{r}=-0.37^{* *}$ & $r=-0.08$ \\
\hline & $\begin{array}{l}\text { Decreased } \\
\text { Personal } \\
\text { Accomplis } \\
\text { hment }\end{array}$ & $r=-0.246^{*}$ & $\mathrm{r}=-0.244^{* *}$ & $\mathrm{r}=0.364^{* * *}$ & $\mathrm{r}=-0.37^{* *}$ & - & $\mathrm{r}=0.24^{* *}$ \\
\hline
\end{tabular}

In the study conducted by Amornpipat (2019) on 305 Thai flight attendants, a negative medium intensity relationship was found between optimism, hope, and resiliency and a decrease in personal 
accomplishment. In the Turkey sample, the intensity of these relationships was found to be weak. However, self-efficacy is associated with all burnout dimensions, as well as hope and optimism only in negative weak intensity with depersonalization. However, the intensity of these relations in Turkey is medium.

Virga et al. (2020) in their study conducted on 193 social workers in Romania, reached different results from the Turkey sample. Resiliency and depersonalization relationship was found to be weak in Turkey while medium in Romania. Also, unlike Turkey, all the results regarding decreased personal accomplishment were found to be insignificant.

Lopez-Nunez et al. (2020), in their study conducted on 517 people working in different sectors, found that the relationships between all sub-dimensions except optimism-emotional exhaustion and hopeemotional exhaustion were found differently from the Turkey sample. Moreover, the relationships between all sub-dimensions of PsyCap and the decreased personal accomplishment dimension of burnout were found to be positive.

As Rattrie et al. (2020) stated, psychological efforts and skills of employees are partly dependent on their national culture. For this reason, it is considered that future meta-analysis studies on the relationship of employees' PsyCap and their burnout levels in different countries can contribute to the elucidation of these partial differences. The results to be obtained in these studies can also shed light on the improvement of the PsyCap of the employees. As suggested by different researchers (Schunk and Hanson, 1985; Snyder, 1994), organizations and managers can use different methods to improve the PsyCap of their employees. Along this line, organizations and hence managers can gain a competitive advantage based on the PsyCap of employees through human resources applications such as selection, training and development.

Undoubtedly, the research has some limitations. The first of these limitations is that studies in which correlation and sample size data which were not reported could not be included in the meta-analysis. The second limitation is that the scans of studies examining the relationship between PsyCap and burnout cover the period between 2012 and until the end of August 2020. The third limitation is that we couldn't reach 
unpublished studies which can cause file drawer problem. But, these shortcomings are generally observed in meta-analysis studies.

Future cross-cultural meta-analysis studies can be conducted within the framework of the Turkish national culture (Owe et al., 2013; Wasti, 2003), which is collectivistic, and the national culture of western countries that exhibit individualistic characteristics. Thus, it will be possible to obtain relatively universal and clearer results regarding the nature of the relationship between PsyCap and burnout.

\section{References}

Altınkurt, Y., Ertürk, A. and Yılmaz, İ. (2015) Öğretmenlerin psikolojik sermayeleri ile tükenmişlik düzeyleri arasındaki ilişki. Journal of Teacher Education and Educators, 4(2), 166-187.

Amornpipat, I. (2019). The relationship between positive psychological capital and job burnout: A study of Thai Airways international flight attendants. Psychology Research, 9(5), 189-196. doi:10.17265/2159$5542 / 2019.05 .001$

Argon, T. and Tükel, H. (2016). Study of school supervisors' organizational psychological capital perception and burnout level. Journal of Contemporary Administrative Science, 1(1), 1-16.

Avey, J.B., Reichard, R., Luthans, F. and Mhatre, K.H. (2011). Meta-Analysis of the impact of positive psychological capital on employee attitudes, behaviors, and performance. Human Resource Development Quarterly, 22(2), 127-152. https://doi.org/10.1002/hrdq.20070.

Avey, J.B., Wernsing, T.S. and Luthans, F. (2008). Can positive employees help positive organizational change? impact of psychological capital and emotions on relevant attitudes and behaviors. Journal of Behavioral Science, 44(1), 48-70. doi 10.1177/0021886307311470.

Bakioğlu, A and Özcan, Ş. (2016). Meta Analiz. (Meta Analysis) Nobel Akademik Yayıncılık Eğitim Danışmanlık.

Bakker, A.B. Van Der Zee, K. I., Lewig, K. A. and Dollard, M. F. (2006). The relationship between the big five personality factors and burnout: A study among volunteer counselors. The Journal of Social Psychology, 146(1), 31-50. doi: 10.3200/SOCP.146.1.31-50.

Bandura, A. (1977). Self-efficacy: Toward a unifying theory of behavioral change. Psychological Review,84(2),191-215. https://doi.org/10.1037/0033-295X.84.2.191. 
Bandura, A. (1997), Self-efficacy: The exercise of control. New York: W.H. Freeman

Bandura, A. and Locke, E. A. (2003). Negative self-efficacy and goal effects revisited. Journal of Applied Psychology, 88(1), 87-99. https://doi.org/10.1037/0021-9010.88.1.87.

Bartlett, J. E., Kotrlik J. W. and Higgins, C. C. (2001). Organizational research: Determining appropriate sample size in survey research. Information Technology. Learning and Performance Journal, 19(1), 43-50.

Begg, C.B. and Mazumdar, M. (1994). Operating characteristics of a rank correlation test for publication bias. Biometrics, 50, 1088-1101. https://doi.org/10.2307/2533446.

Blau, P. M. (1964). Exchange and power in social life. New York, NY: Wiley.

Borenstein, M., Hedges, L. V., Higgins, J. P. T. and Rothstein, H. R. (2009). Introduction to Meta-Analysis. West Sussex, UK: John Wiley \& Sons, Ltd.

Chartrand, T. L. and Cheng, C. M. (2002). The role of nonconscious goal pursuit in hope. Psychological Inquiry, 13(4), 290-294.

Cohen, L., Manion, L. and Morrison, K. (2007). Research methods in education. (sixth ed.). New York: Routledge. https://doi.org/10.1111/j.14678527.2007.00388_4.x.

Datu, J. A. D., King, R. and Valdez, J. P. M. (2016). Psychological capital bolsters motivation, engagement, and achievement: Cross-sectional and longitudinal studies. The Journal of Positive Psychology, 13(3), 260-270. https://doi.org/10.1080/17439760.2016.1257056.

Dinçer, S. (2014). Eğitim Bilimlerinde Uygulamalı Meta-Analiz (Applied MetaAnalysis in Educational Sciences). Pegem Academy, Turkey. ISBN 978605-364-844-4.

Ding, Y., Yang, Y., Yang, X., Zhang, T., Qiu, X., He, X., Wang. W., Wang, L. and Sui, H. (2015). The mediating role of coping style in the relationship between psychological capital and burnout among Chinese nurses. PLoS One, 10(4),1-14. doi: 10.1371/journal.pone.0122128.

El, İ. (2019). The effects of psychological capital and social capital on nurses' work engagement and burnout. Graduate School of Social Sciences, Middle East Technical University, Turkey. Unpublished master thesis. 
Enderoğlu, E. G. (2018). Bilişim sektöründe çalışan bireylerde pozitif psikolojik sermaye ile tükenmişlik belirtileri arasındaki ilişkinin incelenmesi (The relationship between positive psychological capital and burnout syndrome among employees in the ICT sector). Social Sciences Institute, Haliç University, Turkey. Unpublished master thesis.

Field, A. P. and Gillett, R. (2010). How to do a meta-analysis. British Journal of Mathematical \& Statistical Psychology, 63(3), 665-694. https://doi.org/10.1348/000711010×502733.

Freudenberger, J. H. (1974). Staff burnout. Journal of Social Issues, 30 (1), 159165.

Gillham, J. E., Shatté, A. J., Reivich, K. J. and Seligman, M. E. (2001). Optimism, pessimism, and explanatory style. Optimism and pessimism: Implications for theory, research, and practice, 53-75. https://doi.org/10.1037/10385-003.

Gohel, K. (2012). Psychological capital as a determinant of employee satisfaction. International Referred Research Journal, 3(36), 34-37.

Halbesleben, J.R. and Buckley, M.R. (2004). Burnout in organizational life, $\begin{array}{llll}\text { Journal of } & \text { Management, }\end{array}$ https://doi.org/10.1016/j.jm.2004.06.004.

Hamuluoğlu, B. (2019). Psikolojik sermaye ile tükenmişlik arasındaki ilişkinin belirlenmesine yönelik bir araştırma. (A research about determination of the relationship between psychological capital and burnout). Kütahya Dumlupinar University. Social Sciences Institute. Department of Business Administration. Unpublished master thesis.

Harter, J. K., Schmidt, F. L. and Hayes, T. L. (2002). Business-unit-level relationship between employees satisfaction, employee engagement and business outcomes: A meta analysis. Journal of Applied Psychology, 87, 268-279. https://doi.org/10.1037/0021-9010.87.2.268.

Hashim, M.K. (2000). Distinctive Capabilities and performance: Empirical evidence from Malaysian SME's. Malaysian Management Journal. 4(12), 51-64.

Hobföll, E. S. (1989). Conservation of resources: A new attempt at conceptualizing stress. American Psychologist, 44(3), 513-524. https://doi.org/10.1037/0003-066X.44.3.513.

Hofstede, G. (2001). Culture's consequences: Comparing values, behaviors, institutions and organizations across nations (2nd ed.). Thousand Oak, CA: Sage. 
Hunter, J. E. and Schmidt, F. L. (2000). Fixed effects vs. random effects metaanalysis models: Implications for cumulative research knowledge. International Journal of Selection and Assessment, 8(4), 275-292. https://doi.org/10.1111/1468-2389.00156.

Jiang, Y., Song, J., Lee, M. and Bong, M. (2014). Self-efficacy and achievement goals as motivational links between perceived contexts and achievement. Educational Psychology, 34, 92- 117. https://doi.org/10.1080/01443410.2013.863831

Kapusuz A. G. and Çavuş, M. F. (2019). The effects of psychological capital on public employees' burnout: An example from Turkey. Journal of Management and Business Administration, Central Europe, Sciendo, 27(2), 33-47. https://doi.org/10.7206/jmba.ce.2450-7814.251.

Katz, D. and Kahn, R.L. (1978). The Social Psychology of Organizations, New York, Wiley.

Leiter, M. P. and Maslach, C. (1988). The impact of interpersonal environment on burnout and organizational commitment. Journal of Organizational Behavior, 9, 297-308.

Lemaire, J. B., and Wallace, J. E. (2017). Burnout among doctors. BMJ, j3360. doi:10.1136/bmj.j3360

Levene, R. A. (2015). Positive psychology at work: psychological capital and thriving as pathways to employee engagement. Master of Applied Positive Psychology (MAPP) Capstone Projects. Paper 88.

Lopez-Nunez, M.I., Rubio-Valdehita, S., Diaz-Ramiro, E.M. and AparicioGarcia, M.E. (2020). Psychological capital, workload, and burnout: what's new? the impact of personal accomplishment to promote sustainable working conditions. Journal Sustainability. 12, 8124. doi:10.3390/su12198124

Luthans, F., Avey, J.B., Avolio, B.J. and Peterson, S.J. (2010). The development and resulting performance impact of positive psychological capital, Human Resource Development Quarterly, 21(1), 41-67. https://doi.org/10.1002/hrdq.20034.

Luthans, F., Avolio, B. J., Walumbwa, F. and Li, W. (2005). The psychological capital of Chinese workers: Exploring the relationship with performance. Management and Organization Review, 1, 247-269. https://doi.org/10.1111/j.1740-8784.2005.00011.x. 
Luthans, F., Avolio, B. J., Avey, J. B. and Norman, S. M. (2007a). Positive psychological capital: Measurement and relationship with performance and satisfaction. Personnel Psychology, 60(3), 541-572. https://doi.org/10.1111/j.1744-6570.2007.00083.x.

Luthans, F., Luthans, K.W. and Luthans, B.C. (2004). Positive psychological capital: Beyond human and social capital. Business Horizons, 47(1), 45-50. https://doi.org/10.1016/j.bushor.2003.11.007.

Luthans, F., Vogelgesang, G. R. and Lester, P. B. (2006). Developing the psychological capital of resiliency. Human Resource Development Review, 5(1), 25-44. doi: 10.1177/1534484305285335.

Luthans, F. and Youssef, C. M. (2004). Human, social and now positive psychological capital management: İnvesting in people for competitive advantage. Organizational Dynamics, 33, 143-160. https://doi.org/10.1016/j.orgdyn.2004.01.003.

Luthans, F. and Youssef, C. M. (2007). Emerging positive organizational behavior. Journal of management, 33(3), 321-349. https://doi.org/10.1177/0149206307300814.

Luthans, F., Youssef, C.M. and Avolio, B.J. (2007b). Psychological capital: Developing the human competitive edge. Oxford University Press.

Marann, B., Aamir, C., Barbara, F., Evelyn, M. and Pauline, W. (2013). Burnout among accounting and finance academics in Ireland. International Journal of Educational Management, 27(2), 127-142. https://doi.org/10.1108/09513541311297513.

Maslach C. (1976). Burned-out. Human Behavior, 5(9), 16-22

Maslach C. (1982). Understanding burnout: definitional issues in analyzing a complex phenomenon. Job Stress and Burnout, 29-40.

Maslach, C. and Goldberg, J. (1998). Prevention of burnout: New perspectives. Applied and Preventive Psychology, 7, 63-74. doi: 10.1016/S0962-1849(98)80022-X.

Maslach, C. and Jackson, S.E., (1981). The measurement of experienced burnout, Journal of Occupational Behavior, II, 99-113.

Maslach, C., Schaufeli, W. and Leiter, M. P. (2001). Job burnout. Annual Review of Psychology, 52, 397-422. https://doi.org/10.1146/annurev.psych.52.1.397. 
Oles, S. K. (2017). The role of psychological capital and the areas of worklife model in predicting job burnout. Eastern Kentucky University, Online Theses and Dissertations, 460. https://encompass.eku.edu/etd/460.

Owe, E., Vignoles, V.L., Becker, M. and Brown, R. (2013). Contextualism as an important facet of individualism-collectivism: Personhood beliefs across 37 national groups. Journal of Cross-Cultural Psychology, 44, 2447. https://doi.org/10.1177\%2F0022022111430255.

Pearlman, B. and Hartman, E. A. (1982). Burnout: Summary and future research. Human Relation, 35(4), 283-305. https://doi.org/10.1177/001872678203500402.

Peterson, C. (2000). The future of optimism. American psychologist, 55(1), 4455. https://psycnet.apa.org/doi/10.1037/0003-066X.55.1.44.

Peterson, S. J. and Luthans, F. (2003). The Positive impact and development of hopeful leaders. Leadership and Organizational Development Journal, 24(1), 26-31. doi: 10.1108/01437730310457302.

Pines, A. and Aronson, E. (1988), Career burnout: causes and cures. New York: Free press

Prahalad, C. K., and Hamel, G. (1990). The core competence of the corporation. Harvard Business Review, 68, 79-91.

Rattrie, L.T.B., Kittler, M.G. and Karsten, P. I. (2020). Culture, burnout, and engagement: A meta-analysis on national cultural values as moderators in JD-R theory. Applied Psychology: An International Review, 69(1), 176-220. doi: 10.1111/apps.12209.

Rehman, S.U., Qingren, C., Latif, Y. and Iqbal, P. (2017). Impact of psychological capital on occupational burnout and performance of faculty members. International Journal of Educational Management, 31(4), 455-469. doi: 10.1108/IJEM-01-2016-0011.

Rosenthal, R. (1979). The file drawer problem and tolerance for null results. Psychological Bulletin, 86(3), 638641. https://doi.org/10.1037/0033-2909.86.3.638

Rosenthal, R. and DiMatteo, M. R. (2001). Meta-analysis: Recent developments in quantitative methods for literature reviews. Annual Review of Psychology, 52(1), 59-82. https://doi.org/10.1146/annurev.psych.52.1.59. 
Schaufeli, W. B. (2017). Burnout: A short socio-cultural history. S. Neckel, A. K. Schaffner, and G. Wagner (Eds.). Burnout, fatigue, exhaustion: an interdisciplinary perspective on a modern affliction (105-127). Palgrave Macmillan. https://doi.org/10.1007/978-3-319-52887-8_5.

Schaufeli, W. B., Leiter, M. P., Maslach, C. and Jackson, S. E. (1996). The MBIGeneral Survey. C. Maslach, S. E. Jackson, ve M. P. Leiter, Maslach Burnout Inventory manual: 19-26. Palo Alto, CA: Consulting Psychologists Press.

Schulman, P. (1995). Explanatory Style and achievement in school and work. In G. M. Buchanan and M. E. Seligman (Eds.), Explanatory Style, 159171, Hillsdale, NJ: Erlbaum.

Schunk, D. H. and Hanson, A. R. (1985). Peer models: influence on children's self-efficacy and achievement. Journal of Educational Psychology, 77(3), 313-322. https://doi.org/10.1037/0022-0663.77.3.313.

Seligman, M. (1998). Learned Optimism. New York: Pocket Books.

Seligman, M. and Csikszentmihalyi, M. (2000). Positive psychology: An introduction. American Psychologist, 55, 5-14. https://doi.org/10.1037/0003-066X.55.1.5.

Snyder, C. R. (1994). The psychology of hope: You can get there from here. Free Press.

Snyder, C. R. (2000). Handbook of hope: Theory, measures and applications. San Diego, CA: Academic Press

Snyder, C. R. (2002). Hope theory: Rainbows in the mind. Psychological inquiry, 13(4), 249-275. https://doi.org/10.1207/S15327965PLI1304_01.

Snyder, C.R., Harris, C., Anderson, J.R., Holleran, S.A., Irving, L.M., Sigmon, S.T., Yoshinoubu, L., Gibb, J., Langelle, C. and Harney, P. (1991). The will and the ways: Development and validation of an individualdifferences measure of hope. Journal of Personality and Social Psychology, 60(4), 570-585. https://doi.org/10.1037//00223514.60.4.570.

Söylemez, M. (2019). Pozitif psikolojik sermaye ile tükenmişlik arasındaki ilişkiler ve bir araştırma (The relationships between positive psychological capital and burnout and a research). Social Sciences Institute, Marmara University. Unpublished master thesis.

Stajkovic, A. D. and Luthans, F. (1998). Self-efficacy and work-related performance: A meta-analysis. Psychological Bulletin, 124, 240-261. https://psycnet.apa.org/doi/10.1037/0033-2909.124.2.240. 
Tetik, H. T., Ataç, L. O. ve Köse, S. (2018). Psikolojik sermaye ile iş doyumu ve performans ilişkisi: Türkiye'de yapılan araştırmalar üzerinden bir meta analizi (The relationship between psychological capital and job satisfaction and performance: A meta-analysis on the studies conducted in Turkey). Atatürk University Journal of Economics and Administrative Sciences, 32, 2, 289-313.

Thompson, K. R., Lemmon, G. and Walter, T. J. (2015). Employee engagement and positive psychological capital. Organizational Dynamics, 3(44), 185-195. http://dx.doi.org/10.1016/j.orgdyn.2015.05.004.

Tokmak, M. (2018). Pozitif psikolojik sermayenin tükenmişlik üzerine etkileri: Kamu çalışanlarına yönelik bir araştırma (The effects of positive psychological capital on burnout: A research aimed at public official). Journal of Management and Economics, 25(3), 863-878. https://doi.org/10.18657/yonveek.419469.

Virga, D., Baciu, E.L., Lazăr, T.A. and Lupsa, D. (2020). Psychological capital protects social workers from burnout and secondary traumatic stress. Sustainability, 12, 1-16, 2246. doi:10.3390/su12062246.

Wasti, S. A. (2003). The influence of cultural values on antecedents of organisational commitment: An individual-level analysis. Applied Psychology: An International Review, 52, 4, 533-554. https://doi.org/10.1111/1464-0597.00150.

Wernsing, T. (2014). Psychological capital: A test of measurement invariance across 12 national cultures. Journal of Leadership \& Organizational Studies, 21(2), 179-190. doi: 10.1177/1548051813515924.

Windle, G. (2011). What is resilience? A review and concept analysis. Reviews in Clinical Gerontology, 21(2), 152-169. https://doi.org/10.1017/S0959259810000420.

Yılmaz, M. (2019). Pozitif psikolojik sermaye ile mesleki tükenmişlik arasındaki ilişkinin analizi: Hemşireler üzerinde yapılan bir araştırma (Analysis of the relationship between positive psychological capital and occupational burnout: A research on nurses). Social Sciences Institute, Nişantaş1 University, Turkey. Unpublished master thesis.

Yorulmaz, Y. İ. and Altınkurt, Y. (2018). The examination of teacher burnout in Turkey: A meta-analysis. Turkish Journal of Education, 7(1), 34-54. https://doi.org/10.19128/turje.348273. 


\section{Citation Information}

Ocak, M. ve Arıkan, Ö. U. (2021). Psychological capital and burnout relationship of employees in Turkey: A meta-analysis within the scope of sub-dimensions. OPUS- Journal of International Society Studies, 18 (Yönetim ve Organizasyon Özel Saysı), 1085-1119. DOI: $10.26466 /$ opus. 905267 